\title{
Article \\ The Absence of the AtSYT1 Function Elevates the Adverse Effect of Salt Stress on Photosynthesis in Arabidopsis
}

\author{
Miroslav Krausko ${ }^{1} \mathbb{D}$, Zuzana Kusá ${ }^{1}$, Darina Peterková ${ }^{1}$, Mária Labajová ${ }^{1}$, Ajay Kumar ${ }^{1} \mathbb{D}$, Andrej Pavlovič $^{2}$, \\ Michaela Bačovčinová ${ }^{3}$, Martin Bačkor ${ }^{3,4}$ and Ján Jásik ${ }^{1, * \mathbb{D}}$
}

1 Department of Experimental Plant Biology, Institute of Botany, Plant Science and Biodiversity Center, Slovak Academy of Sciences, 84523 Bratislava, Slovakia; miroslav.krausko@savba.sk (M.K.); kusa.zuzana@savba.sk (Z.K.); darina.peterkova@savba.sk (D.P.); maria.labajova@savba.sk (M.L.); ajay.kumar@savba.sk (A.K.)

2 Department of Biophysics, Faculty of Science, Palacký University, 78371 Olomouc, Czech Republic; andrej.pavlovic@upol.cz

3 Department of Botany, Institute of Biology and Ecology, Faculty of Science, Pavol Jozef Šafárik University, 04154 Kosice, Slovakia; michaela.bacovcinova@upjs.sk (M.B.); martin.backor@upjs.sk (M.B.)

4 Department of Biochemistry and Biotechnology, Institute of Biotechnology Faculty of Biotechnology and Food Sciences, Slovak University of Agriculture, 94976 Nitra, Slovakia

* Correspondence: jan.jasik@savba.sk

check for updates

Citation: Krausko, M.; Kusá, Z.; Peterková, D.; Labajová, M.; Kumar, A.; Pavlovič, A.; Bačovčinová, M.; Bačkor, M.; Jásik, J. The Absence of the AtSYT1 Function Elevates the Adverse Effect of Salt Stress on Photosynthesis in Arabidopsis. Int. J. Mol. Sci. 2022, 23, 1751. https:// doi.org/10.3390/ijms23031751

Academic Editor: Ricardo Aroca

Received: 17 January 2022

Accepted: 1 February 2022

Published: 3 February 2022

Publisher's Note: MDPI stays neutral with regard to jurisdictional claims in published maps and institutional affiliations.

Copyright: (C) 2022 by the authors. Licensee MDPI, Basel, Switzerland. This article is an open access article distributed under the terms and conditions of the Creative Commons Attribution (CC BY) license (https:// creativecommons.org/licenses/by/ $4.0 /)$.

\begin{abstract}
Arabidopsis thaliana SYNAPTOTAGMIN 1 (AtSYT1) was shown to be involved in responses to different environmental and biotic stresses. We investigated gas exchange and chlorophyll $a$ fluorescence in Arabidopsis wild-type (WT, ecotype Col-0) and atsyt1 mutant plants irrigated for $48 \mathrm{~h}$ with $150 \mathrm{mM} \mathrm{NaCl}$. We found that salt stress significantly decreases net photosynthetic assimilation, effective photochemical quantum yield of photosystem II $\left(\Phi_{\mathrm{PSII}}\right)$, stomatal conductance and transpiration rate in both genotypes. Salt stress has a more severe impact on atsyt1 plants with increasing effect at higher illumination. Dark respiration, photochemical quenching (qP), non-photochemical quenching and $\Phi_{\text {PSII }}$ measured at $750 \mu \mathrm{mol} \mathrm{m}^{-2} \mathrm{~s}^{-1}$ photosynthetic photon flux density were significantly affected by salt in both genotypes. However, differences between mutant and WT plants were recorded only for $\mathrm{qP}$ and $\Phi_{\mathrm{PSII}}$. Decreased photosynthetic efficiency in atsyt1 under salt stress was accompanied by reduced chlorophyll and carotenoid and increased flavonol content in atsyt1 leaves. No differences in the abundance of key proteins participating in photosynthesis (except PsaC and PsbQ) and chlorophyll biosynthesis were found regardless of genotype or salt treatment. Microscopic analysis showed that irrigating plants with salt caused a partial closure of the stomata, and this effect was more pronounced in the mutant than in WT plants. The localization pattern of AtSYT1 was also altered by salt stress.
\end{abstract}

Keywords: Arabidopsis thaliana; SYNAPTOTAGMIN 1; salt stress; photosynthesis; stomata

\section{Introduction}

Unlike animals, plants are sessile organisms that must deal with an ever-changing environment from which they cannot escape. They have developed diverse survival mechanisms, and plenty of genes, including plant synaptotagmins (SYTs) that help them to last in adverse conditions have been identified [1]. Plant SYTs are orthologues of animal SYTs, well-known calcium sensors that participate in the release of neurotransmitters at the synapses of their neuronal systems [2], and recently discovered extended SYTs (E-SYTs) [3]. PSYTs contain, similarly to classical SYTs, an N-terminal transmembrane sequence and two closely spaced C2 domains and an additional synaptotagmin-like mitochondrial-lipid binding protein (SMP) domain, which is characteristic of E-SYTs. E-SYTs contain three or five tandem C2 domains [3].

Arabidopsis has a small synaptotagmin family that is comprised of six members [4,5], and among them, AtSYT1 is ubiquitously, and the most abundantly expressed [6]. Protein 
was initially found to be enriched in the insolubilized fraction during cold acclimation [7]. Later, mutant and knockdown atsyt1 seedlings were demonstrated to be hypersensitive to damage by salt [6] and cold [8]. It was also proposed that AtSYT1 facilitates adaptive responses to mechanic [9] and ionic stress [10]. Further study revealed that AtSYT1overexpressed plants exhibit reduced membrane lipid peroxidation, upregulated heat shock transcription factors, and heat shock proteins [11]. AtSYT1 is also involved in the response to pathogen attacks. The participation of AtSYT1 in the movement of different viruses between cells through plasmodesmata is well documented [12-16]. Finally, AtSYT1 negatively controls immune secretory pathways to powdery mildew fungi infection by regulating the steady-state levels of the plasma membrane (PM) syntaxin PEN1 [17]. AtSYT1 protein is localized in the PM and the endomembrane system [6,8,12], and in particular, it is enriched at endoplasmic reticulum (ER)-PM contact sites (ER-PM CS) $[9,10,13,18,19]$.

The exact mechanisms by which AtSYT1 is involved in the various processes are not established in detail. Pioneering studies disclosed the involvement of the protein in maintaining the PMintegrity by resealing it after damage by salt and cold $[6,8]$. Recent studies revealed the crucial function of AtSYT1 in tethering cortical ER and PM. It should stabilize the ER network at ER-PM CS [9,10,18,19]. Salt stress causes an increase in AtSYT1 abundance at ER-PM CS and their expansion [10]. AtSYT5 [20] and AtSYT3 [21] homologs are also present at ER-PM CS and these three proteins are likely functionally redundant there. The current view is that the N-terminal transmembrane domain of AtSYT1 and other AtSYTs anchor protein to the ER, C2 domains ensure $\mathrm{Ca}^{2+}$ dependent ER-PM tethering and an SMP domain transfers lipids between the PM and the ER. Abiotic stress such as salinity causes PM instability by accumulating diacylglycerol (DAG) and SYTs as tethers between the ER, and the PM could help maintain PM homeostasis by transporting DAG to the ER $[10,21]$.

Soil salinization is a problem in many countries, and crop loss due to salinity is an increasing threat to agriculture worldwide [22]. All critical physiological processes in plants are directly or indirectly affected by salt stress, and among them, photosynthesis is generally significantly impaired by this stressor [23]. Here we present data demonstrating that the absence of the ATSYT1 gene function increases the adverse effect of salt treatment on this crucial process in the model plant organism, Arabidopsis thaliana.

\section{Results}

\subsection{Gas Exchange and Chlorophyll a Fluorescence Measurements}

In previous studies on AtSYT1, salt stress was estimated exclusively on seedlings growing under in vitro conditions, but experiments on advanced plants are lacking. Salt stress profoundly reduces the efficiency of photosynthesis; therefore, we wished to verify if AtSYT1 has a role in the tolerance to salt stress in regard to this essential physiological process in green plants. We investigated gas exchange and chlorophyll $a$ fluorescence in wild-type (WT) and atsyt1 plants watered for $48 \mathrm{~h}$ with $150 \mathrm{mM} \mathrm{NaCl}$ and compared them with plants irrigated with tap water. The measurement of the gas exchange in WT and mutant plants revealed no significant differences in the light response curves of the net photosynthesis $\left(\mathrm{A}_{\mathrm{N}}\right)$ to increasing photosynthetic photon flux density (PPFD) when the soil was soaked with tap water (Figure $1 \mathrm{~A}$ ). Salt treatment significantly decreased $\mathrm{A}_{\mathrm{N}}$ in both genotypes compared to untreated plants with a more substantial impact on atsyt 1 than WT plants, mainly at higher illumination (Figure 1A). The light response curve of effective photochemical quantum yield of photosystem II ( $\left.\Phi_{\text {PSII }}\right)$ (Figure 1B), which was measured simultaneously with gas exchange, matched well with decreased $A_{N}$ in response to salt stress. Lower $\Phi_{\mathrm{PSII}}$ was also significantly connected with atsyt1 mutation. Again, no differences were observed between WT and atsyt1 plants when irrigated with tap water. Stomatal conductance $\left(g_{s}\right.$, Figure 1C) and rate of transpiration (E, Figure 1D) increased with increasing PPFD, and for both parameters, no differences were revealed between WT and atsyt1 plants when the soil was moistened with tap water. However, salt stress reduced $g_{s}$ and $E$ at each PPFD value, and a significant difference occurred between WT and 
mutant plants. The increases in the $\mathrm{g}_{\mathrm{s}}$ and $\mathrm{E}$ when the light intensity increased were more inhibited in AtSYT1 gene-defective plants than in WT (Figure 1C,D). The intercellular $\mathrm{CO}_{2}$ concentration $\left(\mathrm{c}_{\mathrm{i}}\right)$ decreased with increasing illumination in all cases, and no significant differences were recorded regardless of salt treatment or genotype (Figure 1E). Other chlorophyll $a$ fluorescence parameters were measured at $750 \mu \mathrm{mol} \mathrm{m}{ }^{-2} \mathrm{~s}^{-1}$ PPFD. The values for photochemical quenching (qP, Figure 2A), non-photochemical quenching (NPQ, Figure $2 B), \Phi_{\text {PSII }}$ (Figure $2 C$ ) and rate of respiration $\left(R_{D}\right.$, Figure $\left.2 D\right)$ were affected by salt treatment in both WT and atsyt1 plants. Significant differences between mutant and WT plants under salt stress were only recorded for $\mathrm{qP}$ and $\Phi_{\text {PSII }}$. The maximum photochemical quantum yields of photosystem II $\left(\mathrm{F}_{\mathrm{v}} / \mathrm{F}_{\mathrm{m}}\right)$ remained stable regardless of genotype or salt treatment (Figure 2E).

A

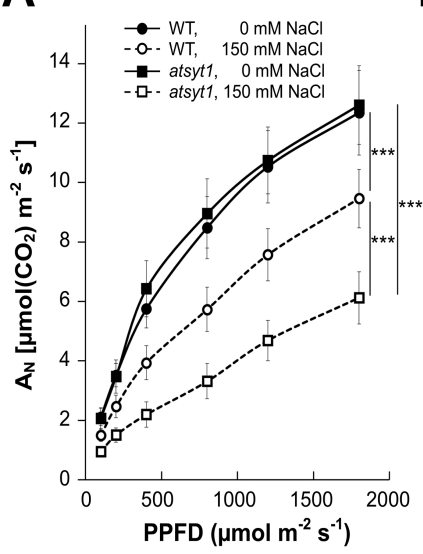

B

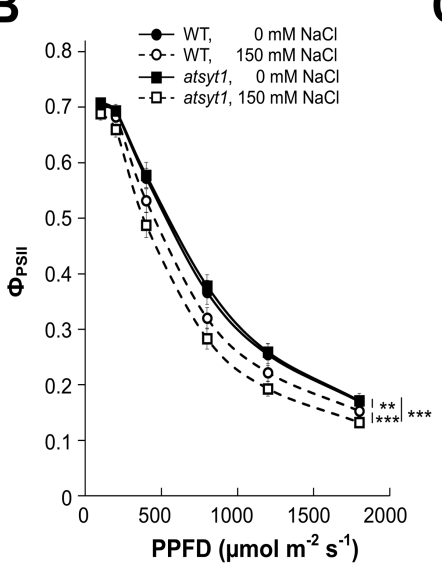

C

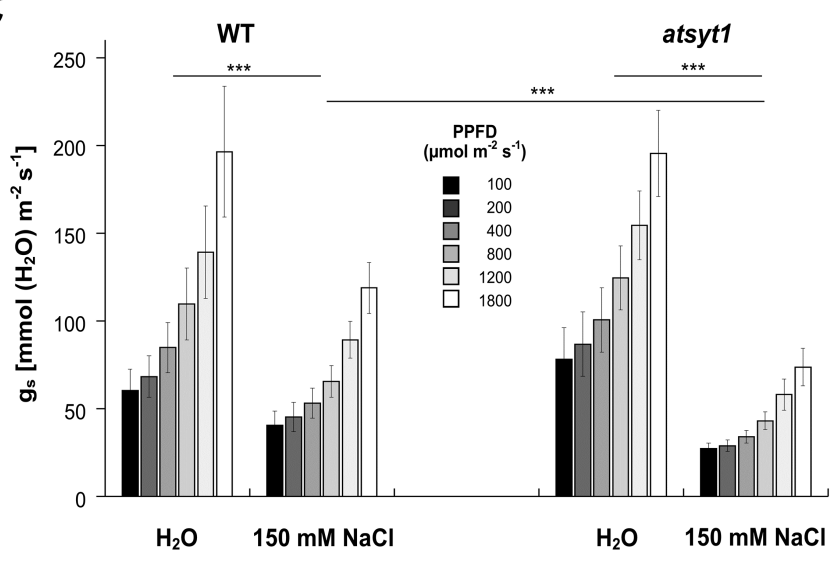

D

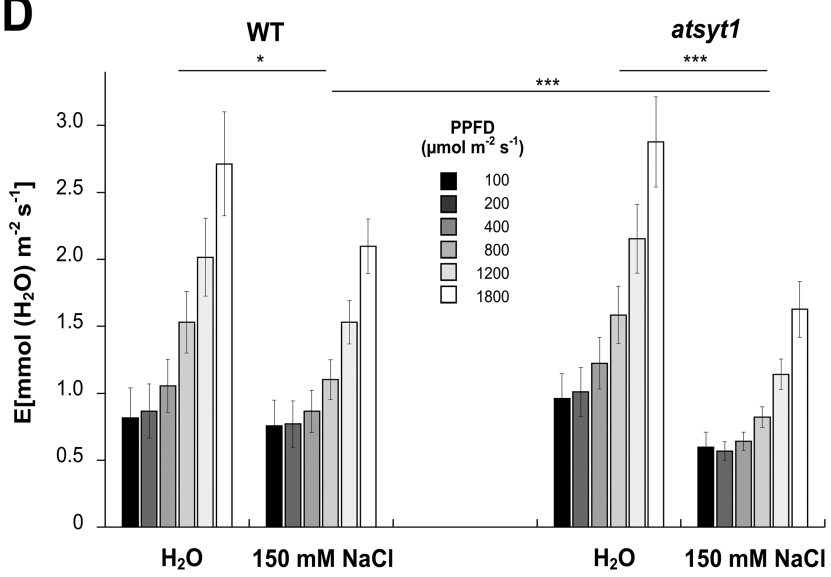

E

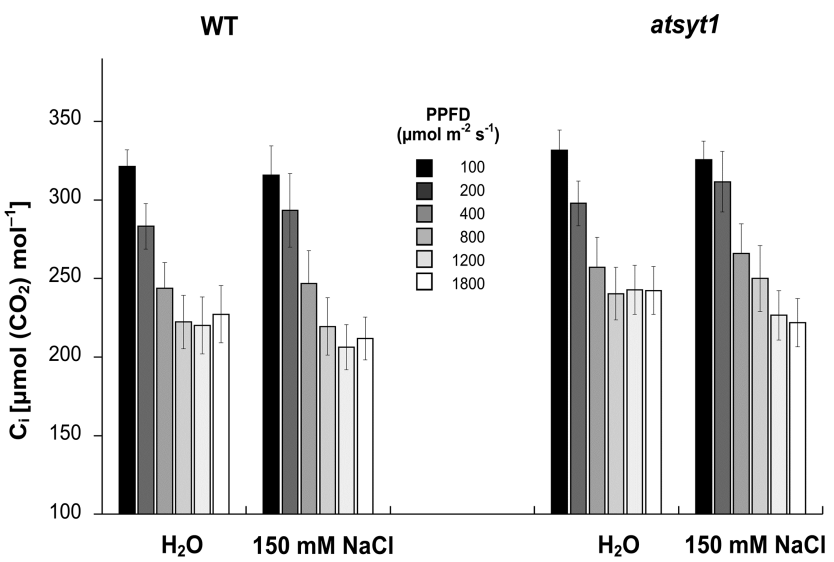

Figure 1. Light response curves for gas exchange and chlorophyll $a$ fluorescence parameters in leaves of wild-type (WT) and atsyt1 plants irrigated with water and $150 \mathrm{mM} \mathrm{NaCl}$. (A) Net photosynthetic rate $\left(\mathrm{A}_{\mathrm{N}}\right)$. (B) The effective photochemical quantum yield of photosystem II ( $\left.\Phi_{\mathrm{PSII}}\right)$. (C) Leaf stomatal conductance $\left(\mathrm{g}_{\mathrm{s}}\right)$. (D) Transpiration rate. (E) Internal $\mathrm{CO}_{2}$ concentrations $\left(\mathrm{c}_{\mathrm{i}}\right)$. Data are shown as means $\pm \mathrm{SE}$ ( $n=8$ for plants irrigated with water and $n=12$ for plants treated with $150 \mathrm{mM}$ salt). Effects of photosynthetic photon flux density (PPFD) in combination with effects of genotype or salt treatment were estimated by a two-way ANOVA test. PPFD showed a statistically highly significant effect $(p \leq 0.001)$ in all cases. Asterisks denote significant effects of genotype or salt treatment $\left({ }^{*} p<0.05,{ }^{* *} p<0.01,{ }^{* * *} p<0.001\right)$.

\subsection{Photosynthetic Protein Abundance}

Since atsyt 1 plants were more sensitive to the toxic effect of salinity in regard to photosynthesis, we tried to find the reason of the lower tolerance of the atsyt1 mutant. Photosynthesis is a complex physiological process with many proteins directly involved 
or participating in the assemblage of photosynthetic protein complexes. In a comprehensive Western blot analysis, we studied the abundance of 20 representative proteins with divergent functions in photosynthesis. We could not find any differences in most estimated proteins (Figure 3A). Only PsaC, a peripheral subunit of the photosystem I complex, and PsbQ, a component of the oxygen-evolving complex of photosystem II, were enriched in extracts derived from salt-stressed plants. Nevertheless, only PsbQ was slightly more abundant in mutant than WT plants (Figure 3B) T when irrigated with the salt solution for $48 \mathrm{~h}$.
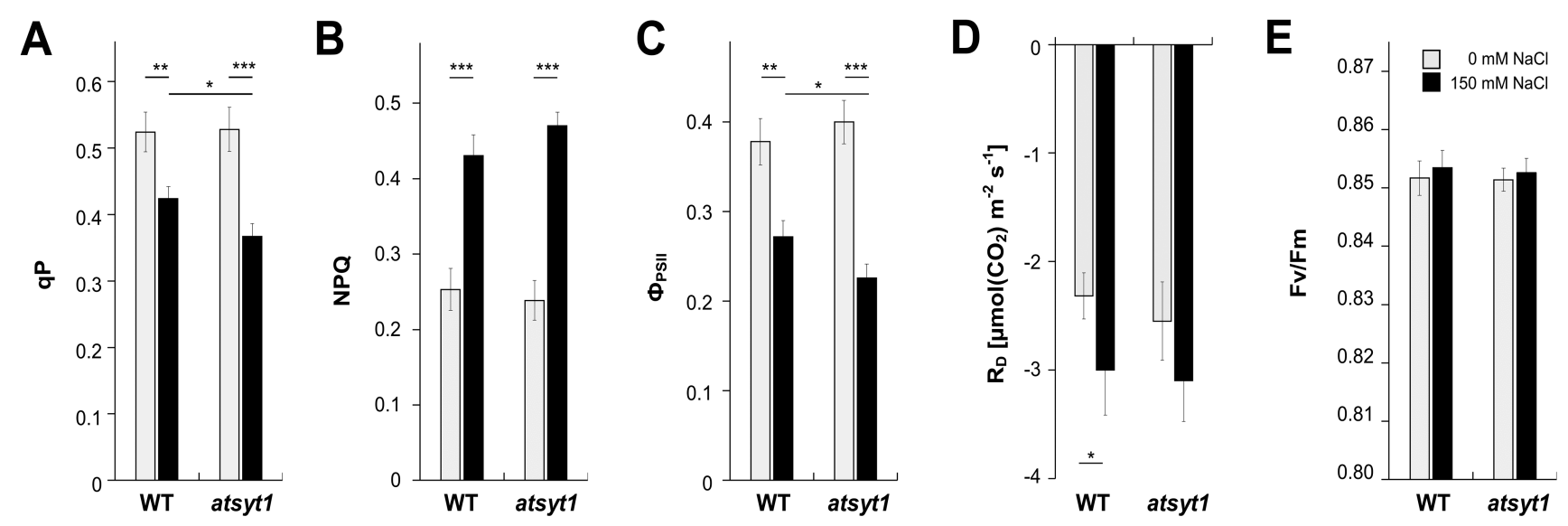

Figure 2. Dark respiration $\left(\mathrm{R}_{\mathrm{D}}\right)$ and chlorophyll $a$ fluorescence parameters in leaves of wild-type (WT) and atsyt1 plants irrigated with tap water and $150 \mathrm{mM} \mathrm{NaCl}$ under constant $750 \mu \mathrm{mol} \mathrm{m}^{-2} \mathrm{~s}^{-1}$ photosynthetic photon flux density (PPFD). (A) Coefficients for photochemical quenching (qP). (B) Coefficients for non-photochemical quenching (NPQ). (C) Effective photochemical quantum yields of photosystem II $\left(\Phi_{\mathrm{PSII}}\right)$. (D) Dark mitochondrial respiration $\left(\mathrm{R}_{\mathrm{D}}\right)$. (E) Maximal quantum yields of photosystem II $\left(\mathrm{F}_{\mathrm{v}} / \mathrm{F}_{\mathrm{m}}\right)$. Asterisks denote significant differences between groups assessed by $t$-test $\left.{ }^{*} p<0.05,{ }^{* *} p<0.01,{ }^{* *} p<0.001\right)$. Data are shown as means $\pm \mathrm{SE}(n=8$ for plants irrigated with water and $n=12$ for plants irrigated with $150 \mathrm{mM}$ salt).

\subsection{Stomata Behavior}

Carbon dioxide is an essential substrate for photosynthesis, and the stomata control its uptake. $A_{N}$ correlates with $g_{s}$, and as we have found both to be more affected in atsyt1 than in WT plants under salt stress (Figure 1C), we analyzed stomata behavior after salt treatment. At first, we studied stomata density, and we did not find a statistically significant difference between mutant and WT plants (Figure 4B). When we compared the stomata lengths, these were similar in both genotypes when plants were irrigated with tap water (Figure $4 \mathrm{~A}$ ). We also did not notice differences between genotypes in the stomata distribution pattern in the leaf epidermis. The stomata become shorter in plants treated with salt, but there was also no difference between mutant and WT plants. The stomata and stomata pore widths were somewhat larger in atsyt1 than WT plants when the soil was soaked with tap water (Figure 4A). Moistening the plants with the salt caused a partial closure of the stomata, and this effect was more pronounced in the mutant than in WT plants (Figure 4A).

\subsection{Content of Pigments}

In the next step, we measured the pigment content, namely, chlorophylls, flavonols and carotenoids. In WT plants, we observed a slight but not significant reduction in the amount of chlorophyll $a$ (Figure 5A), chlorophyll $b$ (Figure 5B) and total chlorophylls (Figure 5C) after salt treatment. However, a decrease in chlorophyll contents in salt-stressed atsyt1 plants was significant compared with salt-treated WT plants or untreated atsyt1. Salt stress resulted in a decreased ratio of chlorophyll $a$ to chlorophyll $b$, but the difference was statistically significant only for WT plants (Figure 5D). The abundance of carotenoids 
was significantly reduced in salt-treated WT plants, and in atsyt plants, this decrease was statistically highly significant (Figure 5E). Flavonols showed the opposite trend, and their content was increased significantly in leaves of salt-stressed mutant plants (Figure 5F).

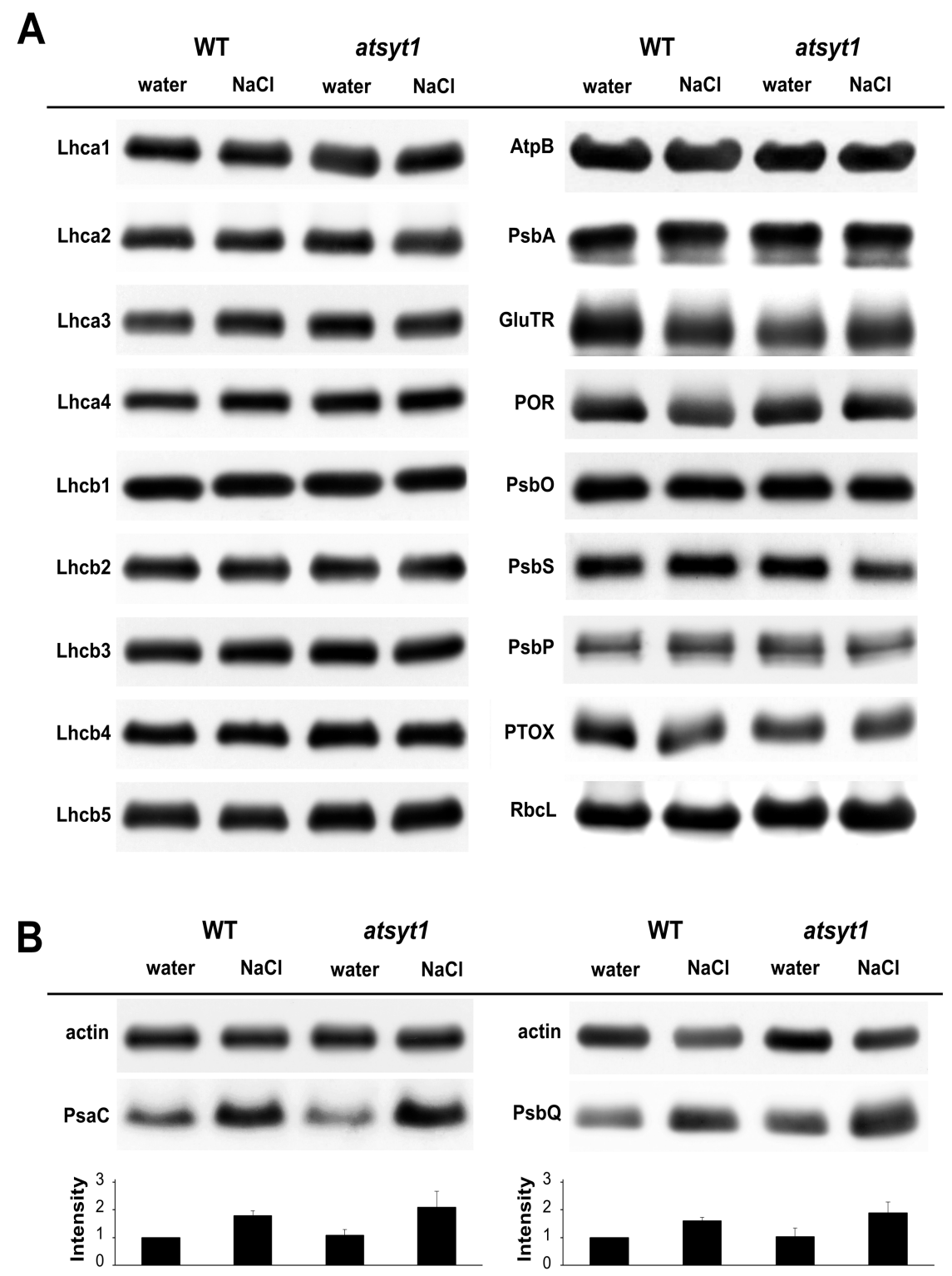

Figure 3. The abundance of photosynthetic proteins in leaves of wild-type (WT) and atsyt1 plants irrigated with tap water or $\mathrm{NaCl}$ solution at $150 \mathrm{mM}$. (A) Proteins of which abundances were not affected by the absence of AtSYT1 and $\mathrm{NaCl}$ treatment. (B) Proteins with increased abundances after irrigation with the salt solution. All experiments were repeated two to four times with similar results. Actin was used as an internal loading control. Intensities of bands were quantified using ImageJ. The values obtained for target proteins were divided by the values for actin for that sample and normalized to the WT irrigated with water. Columns in the graph represent the means of four repetitions of the blots, and bars represent $\mathrm{SE}$.

\subsection{AtSYT1 Dynamics in Guard Cells}

As we found that stomata react profoundly to $\mathrm{NaCl}$ treatment, we wished to verify if the distribution of AtSYT is also affected by salt in stomata guard cells. We examined cotyledons of 5-day-old AtSYT1-Dendra2 seedlings and leaves of 10-day-old AtSYT1GFP seedlings growing in vitro. Using the equatorial optical section, we found that the signal emitted by AtSYT1-Dendra (cotyledons) and AtSYT1-GFP (leaves) was prominent in guard cells at their periphery and especially enriched at the junctions between the stoma 
guard cells (Figure 6A,B). Pavement cells' peripheries showed lower signal intensities than guard cells (Figure 6B). The green signal was also observable inside the cells, especially around chloroplasts (Figure 6C). In a photoconvertible experiment, we also noted that the fluorescence signal surrounding the pore was an unspecific autofluorescence (Figure 6A). When we estimated the localization pattern of AtSYT1 on optical sections through the top and bottom of guard cells, we observed a densely punctate appearance that was distinguishable from adjacent cells in untreated plants (Figure 6D). In seedlings treated with $150 \mathrm{mM}$ salt for $24 \mathrm{~h}$, the signal in the upper periphery of guard cells shows the reticular shape. However, in the bottom section, we observed a densely punctate arrangement (Figure 6E).

A

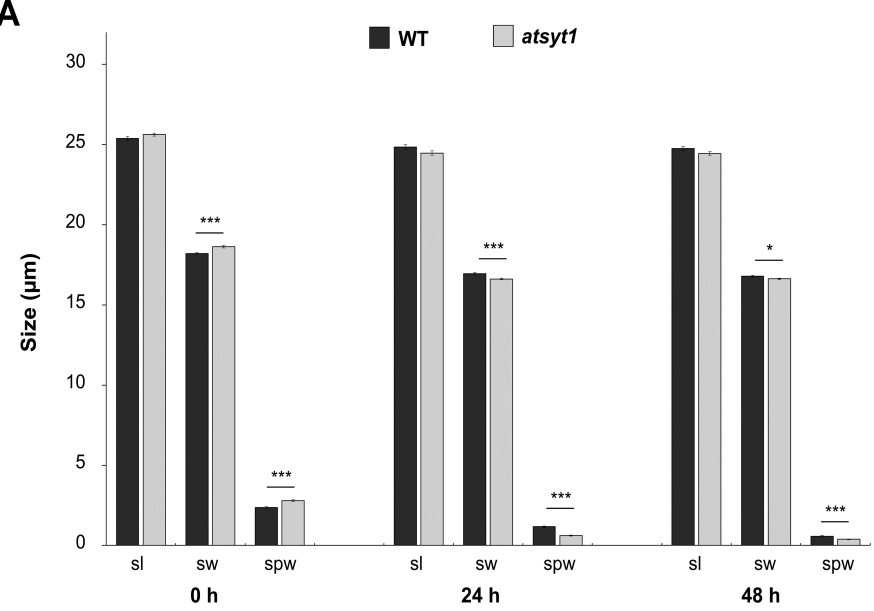

B

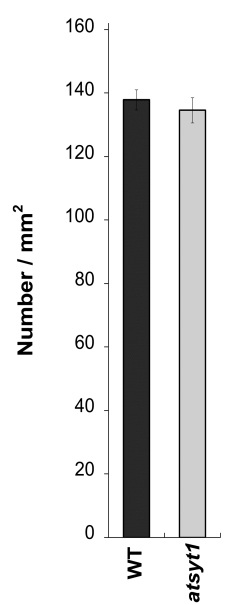

Figure 4. Effect of salt on stomata parameters in WT and atsyt1 plants. (A) Stomata length (sl), width (sw), and pore width (spw). (B) Densities of stomata. Asterisks denote significant differences between groups assessed by $t$-test $\left({ }^{*} p<0.05,{ }^{* * *} p<0.001\right)$. Data are shown as means $\pm \mathrm{SE}(n \geq 500$ in $(\mathbf{A})$, $n=100$ in $(\mathbf{B}))$.
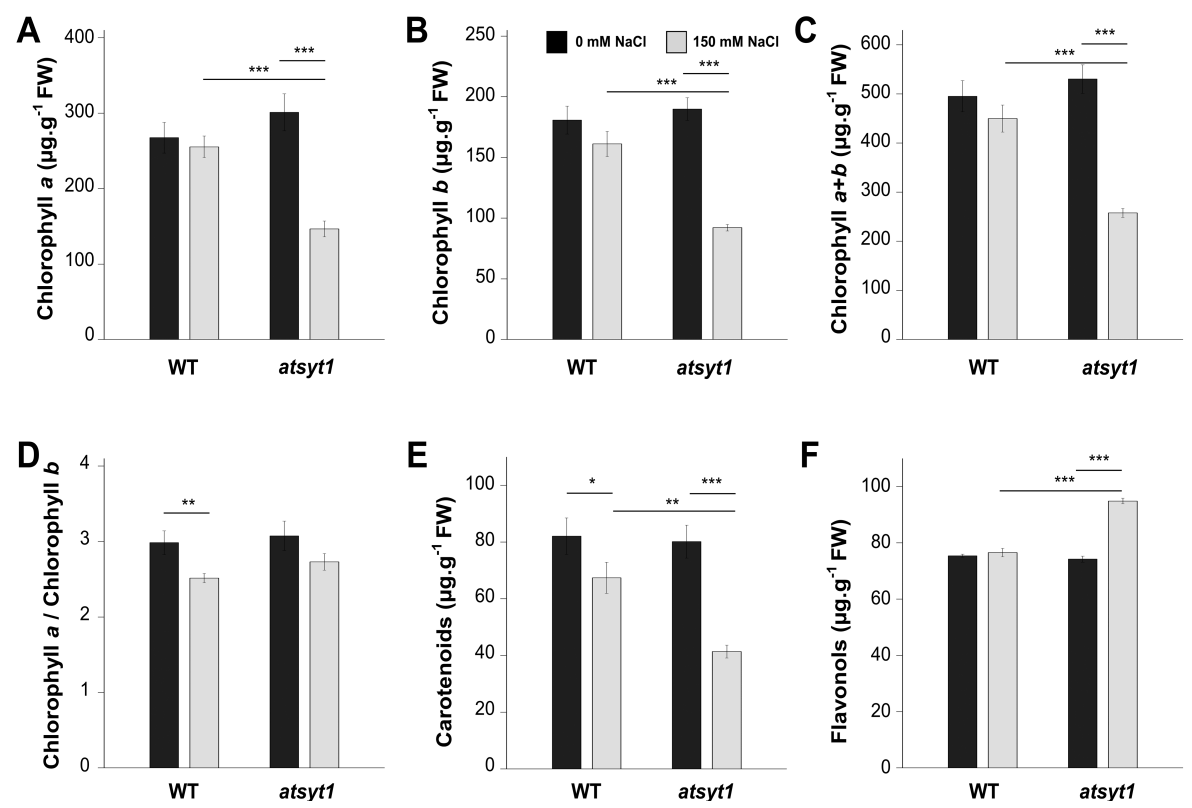

Figure 5. Pigments contents in leaves of salt-stressed wild-type (WT) and atsyt1 plants. (A) Chlorophyll $a$. (B) Chlorophyll $b$. (C) Total amounts of chlorophylls. (D) Chlorophyll $a$ to chlorophyll $b$ ratio. (E) Carotenoids. (F) Flavonols. Asterisks denote significant differences between groups assessed by $t$-test $\left({ }^{*} p<0.05,{ }^{* *} p<0.01,{ }^{* * *} p<0.001\right)$. Data are shown as means $\pm \mathrm{SE}(n=45$ in $(\mathbf{A}-\mathbf{E}), n=15$ in $(\mathbf{F}))$. 

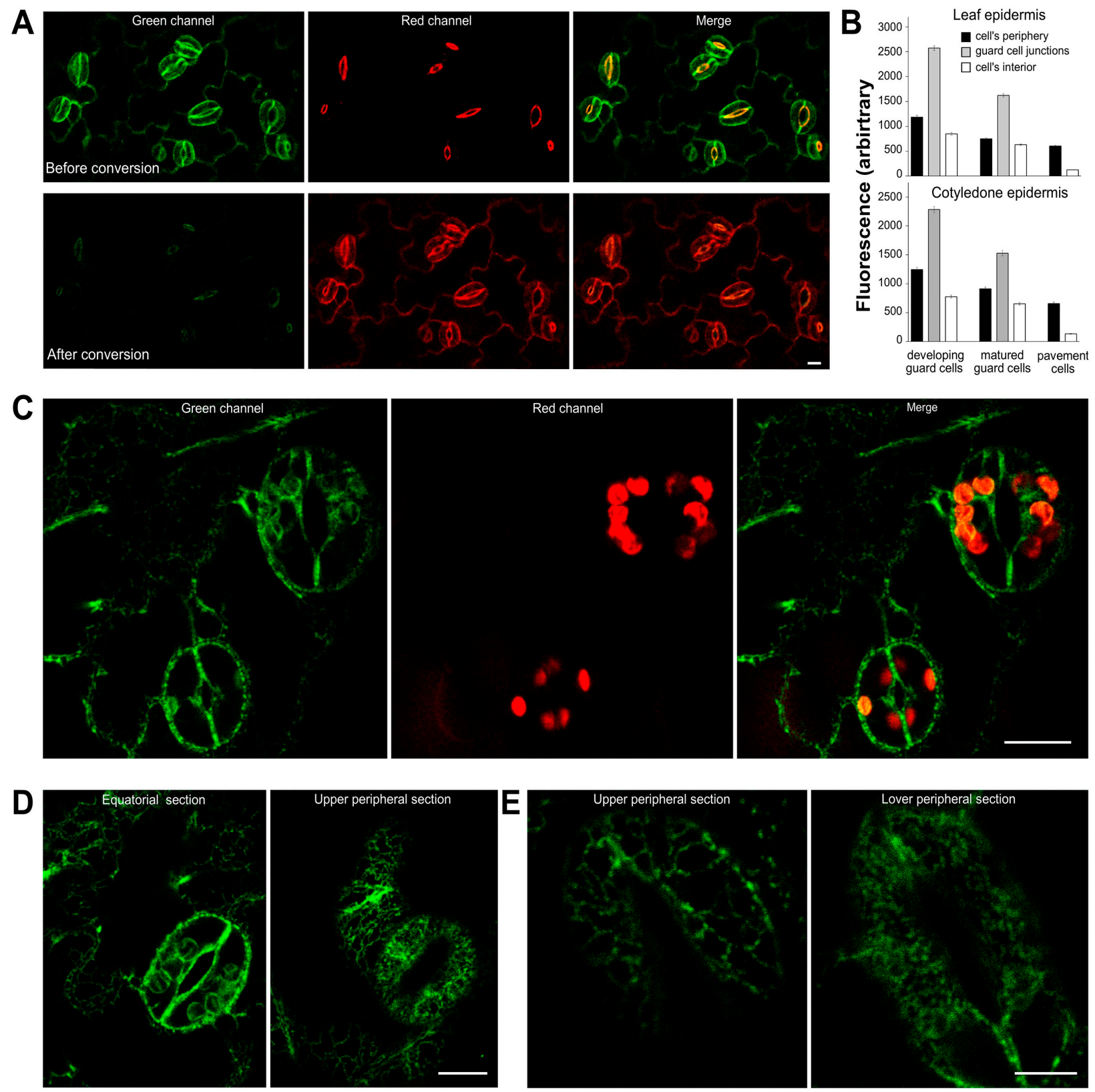

Figure 6. AtSYT1 in guard cells. (A) The red signal observed before photoconversion in guard cells of AtSYT1-Dendra2 plants and the green signal visible after photoconversion represent autofluorescence. Bar $=10 \mu \mathrm{M}$. (B) Fluorescence signal intensities in epidermal cells of seedling leaves of AtSYT1-GFP and cotyledons of AtSYT1-Dendra2. Data are shown as means \pm SE ( $n \geq 150)$. (C) AtSYT1-GFP in leaf epidermal cells. The red signal is emitted by chloroplast. Bar $=10 \mu \mathrm{M}$. (D) AtSYT1-GFP in guard cell of the seedling leaf. Bar $=10 \mu \mathrm{M}$. (E) AtSYT1-GFP at the upper and lower peripheries of the guard cells in the seedling leaf treated by $150 \mathrm{mM} \mathrm{NaCl}$ for $24 \mathrm{~h}$. Bar $=5 \mu \mathrm{M}$.

\section{Discussion}

Originally, AtSYT1 was shown to participate in membrane resealing in the roots of the model organism Arabidopsis thaliana under salt and cold stress [6,8]. However, later studies have documented that the role of this protein in stress responses is more complex $[9-13,17,19]$. Only seedlings that are several days old and growing in vitro have been analyzed in previous studies. In the present study, we examined more advanced plants grown in soil. It is well known that salt stress profoundly reduces the efficiency of photosynthesis [24]; therefore, we wished to verify if AtSYT1 has a role in the tolerance to 
salt stress with regard to this process. We note here that the absence of AtSYT1 impacts the deteriorating effect of salinity on photosynthesis, a crucial physiological process occurring in plants. We considered the results of the previous high-throughput phenotyping study by Awlia et al. [25] in the design of our experiments, and treated plants in an intensive growth period with $150 \mathrm{mM} \mathrm{NaCl}$ for two days to find differences between genotypes. We have established, as expected, that salt-stressed plants display lower photosynthesis efficiency in regard to almost all of the investigated parameters under salt stress. Importantly we also found that atsyt1 plants are more sensitive to salt stress regarding photosynthesis than WT plants.

Salinity is well known to affect photosynthetic capability in many plant species, and potential reasons have been intensively discussed [24,26-31].

Generally, the salt stress may decrease the $A_{N}$ due to its osmotic and toxic effects and through stomatal and non-stomatal modes. Stomatal limitation occurs shortly after the stress manifests itself in the plant's physiological response [32]. Stomatal behavior alone could be responsible for a two-fold decrease in the photosynthesis rate in the light $[33,34]$. A prolonged stress period or combination of stresses usually result in nonstomatal limitation through photoinhibition of PSII or inactivation of some enzymes in the Calvin-Benson cycle [35-37]. We found common reactions to salt stress observed in different plant species previously, such as decreasing $A_{N}, g_{s}, E, q P, \Phi_{P S I I}$ or increasing NPQ (Figures 1 and 2) [38-42]. On the other side, $c_{i}$ and $F_{v} / F_{m}$ were not affected (Figures $1 \mathrm{E}$ and $2 \mathrm{E}$ ). The unchanged $\mathrm{F}_{\mathrm{v}} / \mathrm{F}_{\mathrm{m}}$ indicates that the salt stress used in this study did not cause significant PSII damage in both genotypes. $\mathrm{F}_{\mathrm{v}} / \mathrm{F}_{\mathrm{m}}$ values were also stable in many different species when exposed to mild salt stress for a few days [43-45]. The activation of NPQ (Figure 2B) in response to salt stress probably sufficiently dissipates excess excitation energy without significant damage of PSII in both genotypes. Therefore, decreased $\Phi_{\text {PSII }}$ is likely a consequence of decreased $A_{N}$ and $g_{s}$, which are tightly coupled [32]. In accordance with the gas exchange data (e.g., $g_{s}$ ), we observed significantly more closed stomata in salt-treated plants (Figure 4A). It is well known that stomata secure $\mathrm{CO}_{2}$ acquisition and prevent desiccation. Salinity causes stomata closure and mesophyll conductance suppression, and accordingly, $\mathrm{A}_{\mathrm{N}}$ may decrease due to $\mathrm{CO}_{2}$ restraint [26]. However, increased duration of salt stress may also inactivate enzymes in the Calvin-Benson cycle [37]. Because $c_{i}$ values were unaffected by salt stress despite lower $g_{s}$ (Figure 1C,E), salt stress might also inhibit some enzymes in the Calvin-Benson cycle. Relative invariability in $c_{i}$ in response to environmental stress conditions has been observed formerly (e.g., [46]) and indicates the existence of a stomata-photosynthesis coupling mechanism.

The inhibition of $A_{N}, g_{s}, E$ and $\Phi_{P S I I}$ by salt stress were significantly stronger in atsyt1 plants (Figure 1). We believe that different stomatal behavior, the sensitivity of the Calvin-Benson reactions and decreased chlorophyll content may be partly behind the lower photosynthetic performance of the atsyt1 mutant. It is well known that optimal stomatal function depends on the patterning of stomata, and the size and density of stomata determine the maximum $g_{s}$ [33]. We estimated all these parameters, and we did not observe any differences between the mutant and WT plants. This finding suggests that both genotypes show similar $g_{s}$ when growing under standard conditions. However, when we analyzed stoma apertures, we observed differences in the extent of the response to salt between genotypes. In fact, atsyt1 showed a more reduced stomata aperture after $24 \mathrm{~h}$ salt treatment than WT plants and mutant stomata were more closed also after $48 \mathrm{~h}$ of treatment than WT stomata in accordance with the parameter of $g_{s}$ (Figures $1 \mathrm{C}$ and $4 \mathrm{~A}$ ). Because significant inhibition of $g_{s}$ in atsyt1 plants did not affect $c_{i}$ values (Figure 1C,E), the increased salt-stress sensitivity of Calvin-Benson cycle enzymes may also be considered in atsyt1. Indeed, lower qP values (Figure 2A) in atsyt1 salt-treated plants indicate increased excitation pressure at PSII as a result of decreased consumption of electrons by the CalvinBenson cycle due to increased enzyme inhibition or decreased $\mathrm{CO}_{2}$ diffusion. However, increased excitation pressure did not cause significant PSII damage in atsyt1 plants as $\mathrm{F}_{\mathrm{v}} / \mathrm{F}_{\mathrm{m}}$ indicates (Figure 2E). 
Salt stress affects the expression of many genes. Recent proteomic studies offer plenty of examples of up- and down-regulation of proteins related to photosynthesis. There is also evidence of salts' effect on the abundance of proteins assessed in the present study by Western blotting assay. Several reports provide information about the increasing abundance of oxygen-evolving complex subunits. Particularly, PsbP protein was enriched in extracts of different plant species subjected to salt stress [47-53]. Nevertheless, in oat leaves, its amount decreased in response to salinity [42]. Also, PsbO was up-and downregulated $[42,49,54,55]$, and PsbQ was upregulated in mulberry [56]. Several proteomic studies have recognized the effect of salt on the abundance of light-harvesting complex proteins from both Lhca $[47,57,58]$ and Lhcb $[47,50,52,56]$ subfamilies. ATP synthase beta subunits $[48,49,51,55,58]$ and the RuBisCO large subunit $[48,52,55,58]$ were shown to be regulated in both directions. The inconsistency in the results may be explained by the influence of many factors such as salt concentration, duration of salt treatment, plant salt sensitivity, genotype and co-application of other protective stimuli with salt.

We evaluated the abundance of twenty essential proteins acting as subunits of various complexes participating in photosynthesis in a comprehensive Western blot assay. With two exceptions, we could not determine significant differences between the two genotypes and between salt-stressed and unstressed plants. PsaC and PsbQ were enriched in salt-stressed plants (Figure 3B). PsbP, which was frequently found to be upregulated in different plants [47-53], was 20\% more abundant in salt-stressed WT plants than unstressed samples in our experiments, but we found no differences for atsyt1. Likely, in our case, photosynthesis was not reduced owing to the diminished amount of protein participating in this process. Probably, $48 \mathrm{~h}$ of salt treatment was too short to cause significant changes in the abundance of studied proteins.

Photosynthetic pigment analysis may also partially explain the reduced photosynthetic capacity in salt-treated atsyt1 plants (Figure 5). During photosynthesis, chlorophyll captures the energy from light, carotenoids have photoprotective and an accessory lightharvesting function [59], and flavonols are antioxidants [60]. It is well known that photosynthetic pigments may be damaged by different stresses, which result in the reduced light-absorbing efficiency of PSI and PSII photosystems [61]. For many plant species, salt stress was shown to decrease the chlorophyll content due to increased levels of the toxic $\mathrm{Na}^{+}$cation $[40,50,62-65]$. A decrease in carotenoids in salt-stressed plants was also reported [66,67]. It is tempting to assume that the decreased amount of chlorophyll in salt-stressed plants in our experiments was due to their breakdown rather than reduced biosynthesis. In fact, we could not find differences in the abundance of key regulatory enzymes involved in the chlorophyll biosynthesis pathway: glutamyl-tRNA reductase 1 (abbreviated as GluTR in Figure 3A) and protochlorophyllide oxidoreductase (abbreviated as POR in Figure 3A).

Finally, we estimated the abundance and localization of AtSYT1 using protein fluorescence tags, GFP and Dendra2 in guard cells of stomata. AtSYT1 has been recently intensively studied in epidermal cells of cotyledons, and its essential function has been proposed at ER-PM CS [9,10,18,19]. We found AtSYT1-GFP and AtSYT1-Dendra2 to be enriched at the periphery of guard cells compared to the surrounding pavement cells, and in particular, fusion proteins accumulated at the junctions between the two guard cells (Figure 6A,B). AtSYT1 was also apparent in the endomembrane system of guard cells (Figure 6C,D). The abundance of AtSYT1 in guard cells indicates that AtSYT1 plays an important role in guard cell function.

Interestingly, the stomata in atsyt 1 were more closed under salt stress than in WT plants, and as a consequence, $g_{s}$ was also significantly reduced in the mutant. Different stimuli regulate stomatal closure and opening, and vesicular trafficking in guard cells plays an essential role in these processes [68]. The participation of animal SYTs in vesicular trafficking is well known [69], and a similar role was suggested for AtSYT1 in Arabidopsis roots under salt stress [6]. The guard cells control stomata closing and reopening, and many plasma membrane proteins or proteins associated with the plasma membrane are 
involved in this process [70]. Logically, plasma membrane proteins need to be speedily recycled through membrane trafficking as stomata respond rapidly to changing environments. There is good evidence for slowing stomatal reopening due to reduced recycling of the KAT1 $\mathrm{K}^{+}$channel from endosomal membranes to the plasma membrane in syp121 mutant [71]. The KAT1 $\mathrm{K}^{+}$channel is responsible for $\mathrm{K}^{+}$uptake by the guard cells, and SYP121, a SNARE member, is an essential player in vesicular trafficking. It was suggested that water flux and the transport of other solutes in guard cells might be directly coordinated with membrane trafficking [70]. AtSYT1 may be directly involved in recycling essential plasma membrane proteins that regulate guard cell contraction and expansion. An indirect mode of AtSYT1 action is also possible as AtSYT1 down-regulates the abundance of SYP121, which is also known as PEN1, possibly through endocytosis (17). Additionally, the role of AtSYT1 in delivering the membranes through exocytosis to the plasma membrane in speedily expanded guard cells or membrane removing from the plasma membrane through endocytosis during guard cells shrinkage should be considered. Finally, the participation of AtSYT1 and AtSYT3 in removing toxic DAG from the plasma membrane under salt stress, as suggested recently by Ruiz-Lopez et al. [21], could play an important role in very active guard cells.

In conclusion, AtSYT1 does not seem to be essential for plants surviving in favorable growing conditions, although it is a more abundantly and ubiquitously expressed member of the SYT family in Arabidopsis [6]. For example, atsyt1 seedlings show unaffected phenotype in vitro when grown on a standard medium, and reduced root growth compared to control seedlings was observed only under salt stress [6]. As demonstrated in the present study, atsyt 1 and wild plants show almost identical photosynthesis parameters when growing in the soil. However, in the mutant plants, responses to sudden salt stress were much stronger in almost all parameters than in WT plants. Recent studies suggest that some AtSYTs may have a redundant function $[20,21]$. Perhaps less abundantly expressed AtSYT3 or AtSYT5 may provide a substitute AtSYT1 function when plants grow in a suitable environment. However, the AtSYT1 function seems to be essential for plants to respond efficiently to different stresses.

\section{Material and Methods}

\subsection{Plant Material, Cultivation Conditions and Salt Treatment}

Seeds of Arabidopsis thaliana, ecotype Col-0 (wild-type, WT) and atsyt1-2 mutant (SAIL_775_A08, [6], referred to here as atsyt1) were sown in pots $(4.5 \mathrm{~cm}$ deep with a radius of $6 \mathrm{~cm}$ ) in a soil substrate (50\% peat moss, 30\% perlite, $20 \%$ sand). Pots with WT and atsyt1 plants were kept in the cultivation room and randomly distributed on shelves under standard conditions: a 16/8-h light/dark cycle, with a light intensity of $150 \mu \mathrm{mol} \mathrm{m}{ }^{-2} \mathrm{~s}^{-1}$, photosynthetic photon flux density (PPFD), a temperature of $22( \pm 0.5){ }^{\circ} \mathrm{C}$ and air humidity of $41-55 \%$. Plants were regularly irrigated with tap water. After ten days, surplus plants were removed, and one plant per pot was kept for experiments. Plants were grown in standard conditions for another three weeks. For all experiments, we used healthy plants, approximately at the stage of inflorescence emergence as characterized by Boyes et al. [72]. Two days before measurements and sample collection, pots were immersed in $150 \mathrm{mM} \mathrm{NaCl}$ dissolved in tap water for $30 \mathrm{~min}$ to saturate the soil and left to drain for $10 \mathrm{~min}$ before being returned to the cultivation shelf. The same procedure was repeated $24 \mathrm{~h}$ later. The control plants were treated similarly with tap water. Plants stressed with $150 \mathrm{mM} \mathrm{NaCl}$ for $48 \mathrm{~h}$ were used for gas exchange, chlorophyll $a$ fluorescence analysis and microscopic stomata parameters assessment. The stomata were also assessed after $24 \mathrm{~h}$ of treatment. For microscopy analysis, we used AtSYT1-Dendra2 and AtSYT1-GFP lines as described previously $[6,73,74]$. Seeds were surface sterilized with $70 \%$ ethanol and $1.5 \%$ $(v / v)$ sodium hypochlorite and germinated on the $\frac{1}{2}$ MSMO medium (\#M6899, Merck KGaA, Darmstadt, Germany) supplemented with $1 \%(w / v)$ sucrose. The medium was solidified with seven g/L agar-agar (\#05039, Merck KGaA, Darmstadt, Germany), and media pH was adjusted to 5.7. For seedling cultivation, we used Petri dishes with a diameter of 
$10 \mathrm{~cm}$. Petri dishes were kept in a growth chamber at $21^{\circ} \mathrm{C}$ and $100 \mu \mathrm{mol} \mathrm{m} \mathrm{m}^{-2} \mathrm{~s}^{-1} \mathrm{PPFD}$ continuous light. After five and ten days, seedlings were moved onto the new medium supplemented with $150 \mathrm{mM} \mathrm{NaCl}$ for $24 \mathrm{~h}$.

\subsection{Simultaneous Measurement of Gas Exchange and Chlorophyll a Fluorescence}

To determine the photosynthetic gas exchange and chlorophyll $a$ fluorescence, we used an infrared gas exchange analyzer Ciras-2 (PP Systems, Hitchin, UK) connected to PLC6 leaf cuvette with attached Fluorcam FC1000LC camera (Photon Systems Instruments, Brno, Czech Republic). WT and atsyt1 plants irrigated with $\mathrm{NaCl}$ or tap water for $48 \mathrm{~h}$ before measurement were initially adapted to dark for $30 \mathrm{~min}$, and then a single leaf of plant was enclosed in the PLC6 leaf cuvette. Minimal fluorescence $\left(\mathrm{F}_{0}\right)$ was quantified using weak light of $0.1 \mu \mathrm{mol} \mathrm{m} \mathrm{m}^{-2} \mathrm{~s}^{-1}$ PPFD, $\lambda=455 \mathrm{~nm}$ and then maximum fluorescence $\left(F_{m}\right)$ was measured with a saturation pulse of $3000 \mu \mathrm{mol} \mathrm{m} \mathrm{m}^{-2} \mathrm{~s}^{-1}$ PPFD, $800 \mathrm{~ms}$ duration, $\lambda=620 \mathrm{~nm}$. The ratio variable/maximum fluorescence $\left(\mathrm{F}_{\mathrm{v}} / \mathrm{F}_{\mathrm{m}}\right)$ was calculated as $\left(\mathrm{F}_{\mathrm{m}}-\mathrm{F}_{0}\right) / \mathrm{F}_{\mathrm{m}}$. The induction curve of photosynthesis was observed for 15 min after turning on an actinic light of intensity of $750 \mu \mathrm{mol} \mathrm{m} \mathrm{m}^{-2} \mathrm{~s}^{-1}$ PPFD. Ten regularly spaced saturation pulses $\left(3000 \mu \mathrm{mol} \mathrm{m}{ }^{-2} \mathrm{~s}^{-1}\right.$ PPFD, $800 \mathrm{~ms}$ duration, $\left.\lambda=620 \mathrm{~nm}\right)$ were triggered during induction measurement to calculate the quenching coefficient. The actinic light was then turned off, and $\mathrm{F}_{0}{ }^{\prime}$ was measured. The parameters $\Phi_{\mathrm{PSII}}, \mathrm{qP}$ and NPQ were calculated according to Maxwell and Johnson [75]. The same enclosed leaf was used to measure the light response curves. After a short relaxation period, until $\mathrm{R}_{\mathrm{D}}$ was measurable, the irradiance of $70 \mu \mathrm{mol} \mathrm{m}{ }^{-2} \mathrm{~s}^{-1}$ PPFD was turned on. After stabilization, the light intensity was increased stepwise (100, 200, 400, 800, 1200 and $1800 \mu \mathrm{mol} \mathrm{m} \mathrm{m}^{-2} \mathrm{~s}^{-1}$ PPFD), and the measurement took $4 \mathrm{~min}$ in each step. At the end of each intensity period, the saturation pulse $\left(3000 \mu \mathrm{mol} \mathrm{m}{ }^{-2} \mathrm{~s}^{-1}\right.$ PPFD, $800 \mathrm{~ms}$ duration, $\lambda=620 \mathrm{~nm}$ ) was applied to determine $\Phi_{\text {PSII }}$. Thus, the light response curves of $A_{N}, E, g_{s}$ and $\Phi_{\text {PSII }}$ were recorded simultaneously. The concentration of $\mathrm{CO}_{2}$ during the whole procedure was set to $400 \mathrm{ppm}$, leaf temperature was kept at $23 \pm 1{ }^{\circ} \mathrm{C}$, and relative air humidity was between 50-55\%. After the measurements were taken, the actinic light was turned off, and after $10 \mathrm{~min}, \mathrm{R}_{\mathrm{D}}$ was measured for $5 \mathrm{~min}$. The leaf area enclosed in the cuvette was determined using calibrated Fluorcam software. The obtained $A_{N}, R_{D}, E$ and $g_{s}$ values were recalculated to account for area differences. Together, eight plants irrigated with tap water and twelve plants watered with a saline solution were used for each genotype.

\subsection{Stomata Density and Size Analysis}

For stomata analysis, fully expanded rosette leaves were collected from plants watered with tap water or $150 \mathrm{mM}$ salt solution for 24 and $48 \mathrm{~h}$. Abaxial sites were immediately coated with a thin layer of clear nail polish. After drying, the polish film was peeled from leaves, moved onto a slide and covered by a coverslip. Five images were captured from each polish replica using an Olympus FV1000 confocal laser scanning microscope (Olympus, Tokyo, Japan) equipped with Levenhuk M1400 PLUS Microscope Digital Camera (Levenhuk, Inc., Tampa, FL, USA) and associated LevenhukLite software. Stomata density was counted over the entire area of the image captured by UPlanFLN $10 \times / 0.30$ objective, which was $0.2622 \mathrm{~mm}^{2}$. Four leaves from each of five plants were collected, so a hundred images were analyzed per WT and atsyt1 seedlings. For the analysis of stomatal dimensions, images were captured using UPlanSApo $60 \times / 1.35$ Oil objective, and the stomata length and width, and pore width of at least 500 stomata were measured using the ImageJ program (NIH, Bethesda, MD, USA).

\subsection{Western Blot Assay}

Total protein extraction was done using a modified EZ procedure [76]. Briefly, $300 \mathrm{mg}$ leaf samples snap-frozen in liquid nitrogen were homogenized in 1.5 Eppendorf microtubes with $1 \mathrm{~mL}$ E-buffer (200 mM Tris-HCl pH 8.8, 10\% glycerol, 1\% SDS, Sigma-Aldrich Protease Inhibitor Cocktail, P9599, Merck KGaA, Darmstadt, Germany) for plant cell and tissue 
extracts) by a metal micro pestle using a hand drill. The extract was centrifuged for 20 min at $16,000 \times g$ and $4{ }^{\circ} \mathrm{C}$, and then $800 \mu \mathrm{L}$ of supernatant was mixed with $200 \mu \mathrm{L}$ Z-buffer (12\% SDS, $10 \%$ glycerol, $22 \% \beta$ - mercaptoethanol, $0.001 \%$ bromophenol blue). All chemicals were obtained from Merck KGaA (Darmstadt, Germany), unless otherwise stated. Protein concentration was determined by the DC Protein assay kit (Bio-Rad Laboratories, Hercules, CA, USA) according to the manufacturer's instructions. All samples were adjusted to the same protein concentration with EZ buffer (E buffer to Z buffer ratio 8:2). After denaturation at $95{ }^{\circ} \mathrm{C}$ for five min, proteins were separated with SDS-PAGE using the Mini-PROTEAN ${ }^{\circledR}$ Tetra electrophoresis system (Bio-Rad) and Tris-Gly buffer (25 mM Tris, $192 \mathrm{mM}$ Gly, and $0.1 \%$ SDS, pH 8.3). Ten micrograms of protein was loaded per lane. $4 \%$ polyacrylamide (Acrylamide/Bis Solution, 29:1, Bio-Rad) in buffer containing $125 \mathrm{mM}$ Tris, 0.1\% SDS, $0.1 \%$ APS and $0.01 \%$ TEMED, pH 6.8 was used in stacking and 8 to $15 \%$ polyacrylamide in buffer consisting of $375 \mathrm{mM}$ Tris, $0.1 \%$ SDS, 0.1 APS $\%$ and 0.01\% TEMED, pH 8.8 in the resolving layer. Separated proteins were transferred onto an Immun-Blot ${ }^{\circledR}$ PVDF Membrane (Bio-Rad) employing a Mini Trans-Blot ${ }^{\circledR}$ Cell system (Bio-Rad) and transfer buffer (25 mM Tris-base, $192 \mathrm{mM}$ glycine, 0.1\% (w/v) SDS, 20\% methanol, $\mathrm{pH}$ 8.3). The membrane was blocked in TBST buffer $(20 \mathrm{mM}$ Tris-HCl, $\mathrm{pH} 7.4,180 \mathrm{mM} \mathrm{NaCl}$, and 0.1\% Tween 20) with 5\% skim milk ((\#42590, SERVA Electrophoresis GmbH, Heidelberg, Germany) for one $\mathrm{h}$ and then probed for $1 \mathrm{~h}$ with primary antibodies diluted in TBS supplemented with 5\% skimmed milk. After that membranes were washed three times with TBST for $10 \mathrm{~min}$ and incubated with appropriate secondary antibody in TBST buffer with 5\% skim milk for $1 \mathrm{~h}$. After washing with TBST (three times for $10 \mathrm{~min}$ ) and TBS (two times $5 \mathrm{~min}$ ), the Clarity Western ECL Substrate (\#1705061, Bio-Rad) was applied onto a membrane, and the light signal from the membrane was captured on photographic paper, which was developed and fixed in the normal way. Membranes were probed with antibody in dilution as follows: Anti-PsbA (D1) (Agrisera, Vännäs, Sweden, AS05 084, 1:20,000), Anti-RbcL (Agrisera, AS03 037, 1:10,000), anti-Lhca1 (Agrisera, AS01 005, 1:15,000), Anti-Lhca2 (Agrisera, AS01 006, 1:25,000), Anti-Lhca3 (Agrisera, AS01 007, 1:7500), Anti-Lhca4 (Agrisera, AS01 008, 1:5000), Anti-Lhcb1 (Agrisera, AS01 004, 1:2000), AntiLhcb2 (Agrisera, AS01 003, 1:20,000), Anti-Lhcb3 (Agrisera, AS01 002, 1:8000), Anti-Lhcb4 (Agrisera, AS04 045, 1:7000), Anti-Lhcb5 (Agrisera, AS01 009, 1:6000), Anti-PsbO (Agrisera, AS06 142-33, 1:10,000), Anti-PsbP (Agrisera, AS06 167, 1:6000), Anti-PsbQ (Agrisera, AS06 142-16, 1:7500), Anti-PsbS (Agrisera, AS09 533, 1:12,000), Anti-GluTR (Agrisera, AS10 689, 1:5000), Anti-POR (Agrisera, AS05 067, 1:2000), Anti-PTOX (Uniplastomic, Biviers, France, AB012, 1:2000), Anti-PsaC (Agrisera, AS10 939, 1:1000), Anti-AtpB (Agrisera, AS05 085 , 1:5000). The protein loading control was performed with a monoclonal anti-actin antibody (Merck KGaA, Darmstadt, Germany, A0480, 1:10,000). Goat anti-rabbit IgG:HRP (Bio-Rad, 403005, 1:10,000) and goat anti-mouse IgG:HRP (Bio-Rad, 103005, 1:10,000) were used as secondary antibodies.

\subsection{Quantification of Chlorophylls, Carotenoids and Flavonoids}

Twenty-five milligrams of fresh leaf samples were ground with $20 \mathrm{mg}$ of sand and $\mathrm{MgCO}_{3}$ mixture (ratio 3:1) and extracted with $1 \mathrm{~mL}$ of $80 \%(v / v)$ chilled acetone. Then the samples were centrifuged at $8000 \times g$ for $5 \mathrm{~min}$ at a temperature of $4{ }^{\circ} \mathrm{C}$. Chlorophylls and total carotenoids in the supernatant were determined spectrophotometrically using a Synergy HT Microplate Reader (BioTek Instruments, Inc., Winooski, VT, USA). Absorbance was measured for chlorophyll $a$ at $663 \mathrm{~nm}$, chlorophyll $b$ at $647 \mathrm{~nm}$, and carotenoids at $470 \mathrm{~nm}$. A background measurement at $710 \mathrm{~nm}$ was subtracted from the pigment absorbance, and the data were evaluated using Gen5 software. Concentrations of assimilation pigments were calculated according to Lichtenthaler [77]. For chlorophyll and carotenoid estimations, five plants per genotype and treatment were used for the experiment, and three samples of leaves were taken for analysis from each plant. The experiment was repeated three times, so the data represented the averages of 45 samples. Total flavonoid contents were determined with the aluminum chloride colorimetric method [78]. One hundred 
milligrams of snap-frozen leaf material was ground, mixed with 50\% methanol, and after vortexing, flavonols were extracted for two h at room temperature. Samples were then centrifuged at $10,000 \times g$ for $5 \mathrm{~min}$. Supernatant or quercetin standards were mixed with an equal volume of $2 \%$ aluminum chloride and incubated for $60 \mathrm{~min}$ at room temperature. The absorbance of the reaction mixtures was measured against blank at $415 \mathrm{~nm}$. The results were derived from the quercetin calibration curve, and the flavonoid content was expressed as $\mu \mathrm{g}$ quercetin equivalents $(\mathrm{QE}) / \mathrm{g}$ fresh mass. Samples collected from individual plants were pooled. Five plans were used for the experiment, and the experiment was repeated three times so that the data represented the averages of 15 samples.

\title{
4.6. Confocal Microscopy
}

Five or ten-day-old seedlings were placed on a microscopic slide covered with 1.5 solidified $\frac{1}{2}$ MSMO medium and covered by a coverslip. Photoconversion of Dendra 2 was achieved using an Olympus FV1000 confocal laser scanning microscope as described previously $[73,74]$. Two-channel images were acquired sequentially in the multi-track mode under the same microscope using 20X Uplan FI (0.50 NA) or 40X UPLSAPO Super Apochromat (0.90) objectives. For Dendra2 detection, the green signal was excited with a $488 \mathrm{~nm}$ line from an argon laser, and the signal was collected with a 505-525 nm band-pass filter. The red signal was excited with a $543 \mathrm{~nm}$ line from a HeNe laser, and fluorescence was collected with a 560-620 nm band-pass filter. For GFP and chlorophyll detection, excitation was done with a $488 \mathrm{~nm}$ line of an argon laser, and signals were collected with 505-525 nm and $610-710$ band-pass filters.

\subsection{Data Evaluation, Processing, and Presentation}

Results are expressed as means \pm SEM. Comparisons between salt-treated and untreated samples and atsyt1 and WT plants were made with a two-way analysis of variance (ANOVA). Differences between WT and mutant plants in stomata parameters, chlorophyll and carotenoid contents were valued using an unpaired Student $t$-test. Graphs were prepared using the Excel program; figures were processed with the Publisher program and Photoshop software. The fluorescence signal intensities and the intensities of bands in Western blot assay were evaluated by the ImageJ package (National Institutes of Health, Bethesda, MD, USA).

\begin{abstract}
Author Contributions: Conceptualization, J.J.; gas exchange and chlorophyll $a$ fluorescence estimation, M.K.; stomata analysis, M.K. and A.K.; Western blot assay, Z.K., D.P. and M.L.; pigment analysis, M.B. (Michaela Bačovčinová) and M.B. (Martin Bačkor); confocal microscopy, J.J.; data analysis, J.J. and M.K.; contribution to material, A.P.; writing the manuscript, J.J.; critical reading the manuscript, M.K. and A.P.; project directing and funding acquisition, J.J. All authors have read and agreed to the published version of the manuscript.
\end{abstract}

Funding: This study was supported by the Slovak Research and Development Agency (grant no. APVV-16-0398).

Institutional Review Board Statement: Not applicable.

Acknowledgments: Seeds of AtSYT1-GFP transgenic and atsyt1-2 mutant lines were a generous gift from Miguel Angel Botella, Universidad de Málaga.

Conflicts of Interest: The authors declare no conflict of interest.

\section{References}

1. Lamers, J.; van der Meer, T.; Testerink, C. How plants sense and respond to stressful environments. Plant Physiol. 2020, 182, 1624-1635. [CrossRef] [PubMed]

2. Bornschein, G.; Schmidt, H. Synaptotagmin $\mathrm{Ca}^{2+}$ sensors and their spatial coupling to presynaptic Cav channels in central cortical synapses. Front. Mol. Neurosci. 2019, 11, 494. [CrossRef]

3. Herdman, C.; Moss, T. Extended-Synaptotagmins (E-Syts); the extended story. Pharmacol. Res. 2016, 107, 48-56. [CrossRef] [PubMed]

4. Craxton, M. Genomic analysis of synaptotagmin genes. Genomics 2001, 77, 43-49. [CrossRef] [PubMed] 
5. Craxton, M. Synaptotagmin gene content of the sequenced genomes. BMC Genom. 2004, 5, 43. [CrossRef] [PubMed]

6. Schapire, A.L.; Voigt, B.; Jasik, J.; Rosado, A.; Lopez-Cobollo, R.; Menzel, D.; Salinas, J.; Mancuso, S.; Valpuesta, V.; Baluska, F.; et al. Arabidopsis synaptotagmin 1 is required for the maintenance of plasma membrane integrity and cell viability. Plant Cell 2008, 20, 3374-3388. [CrossRef]

7. Kawamura, Y.; Uemura, M. Mass spectrometric approach for identifying putative plasma membrane proteins of Arabidopsis leaves associated with cold acclimation. Plant J. 2003, 36, 141-154. [CrossRef]

8. Yamazaki, T.; Kawamura, Y.; Minami, A.; Uemura, M. Calcium-dependent freezing tolerance in Arabidopsis involves membrane resealing via synaptotagmin SYT1. Plant Cell 2008, 20, 3389-3404. [CrossRef]

9. Pérez-Sancho, J.; Vanneste, S.; Lee, E.; McFarlane, H.; del Valle, A.E.; Valpuesta, V.; Friml, J.; Botella, M.A.; Rosado, A. The Arabidopsis SYT1 is enriched in ER-PM contact sites and confers cellular resistance to mechanical stresses. Plant Physiol. 2015, 168, 132-143. [CrossRef]

10. Lee, E.; Vanneste, S.; Pérez-Sancho, J.; Benitez-Fuente, F.; Strelau, M.; Macho, A.P.; Botella, M.A.; Friml, J.; Rosado, A. Ionic stress enhances ER-PM connectivity via phosphoinositide-associated SYT1 contact site expansion in Arabidopsis. Proc. Natl. Acad. Sci. USA 2019, 116, 1420-1429. [CrossRef]

11. Yan, Q.; Huang, Q.; Chen, J.; Li, J.; Liu, Z.; Yang, Y.; Li, X.; Wang, J. SYTA has positive effects on the heat resistance of Arabidopsis Plant Growth Reg. 2017, 81, 467-476. [CrossRef]

12. Lewis, J.D.; Lazarowitz, S.G. Arabidopsis synaptotagmin SYTA regulates endocytosis and virus movement protein cell-to-cell transport. Proc. Natl. Acad. Sci. USA 2010, 107, 2491-2496. [CrossRef]

13. Levy, A.; Zheng, J.Y.; Lazarowitz, S.G. Synaptotagmin SYTA forms ER-plasma membrane junctions that are recruited to plasmodesmata for plant virus movement. Curr. Biol. 2015, 25, 2018-2025. [CrossRef] [PubMed]

14. Uchiyama, A.; Shimada-Beltran, H.; Levy, A.; Zheng, J.Y.; Javia, P.A.; Lazarowitz, S.G. The Arabidopsis synaptotagmin SYTA regulates the cell-to-cell movement of diverse plant viruses. Front. Plant Sci. 2014, 5, 584. [CrossRef] [PubMed]

15. Yuan, C.; Lazarowitz, S.G.; Citovsky, V. The plasmodesmal localization signal of TMV MP is recognized by plant synaptotagmin SYTA. mBio 2018, 9, e01314-18. [CrossRef] [PubMed]

16. Cabanillas, D.G.; Jiang, J.; Movahed, N.; Germain, H.; Yamaji, Y.; Zheng, H.; Laliberté, J.F. Turnip mosaic virus uses the SNARE protein VTI11 in an unconventional route for replication vesicle trafficking. Plant Cell 2018, 30, 2594-2615. [CrossRef]

17. Kim, H.; Kwon, H.; Kim, S.; Kim, M.K.; Botella, M.A.; Yun, H.S.; Kwon, C. Synaptotagmin 1 negatively controls the two distinct immune secretory pathways to powdery mildew fungi in Arabidopsis. Plant Cell Physiol. 2016, 57, 1133-1141. [CrossRef]

18. Siao, W.; Wang, P.; Voigt, B.; Hussey, P.J.; Baluska, F. Arabidopsis SYT1 maintains stability of cortical endoplasmic reticulum networks and VAP27-1-enriched endoplasmic reticulum-plasma membrane contact sites. J. Exp. Bot. 2016, 67, 6161-6171. [CrossRef]

19. Ishikawa, K.; Tamura, K.; Ueda, H.; Ito, Y.; Nakano, A.; Hara-Nishimura, I.; Shimada, T. Synaptotagmin-associated endoplasmic reticulum-plasma membrane contact sites are localized to immobile ER tubules. Plant Physiol. 2018, 178, 641-653. [CrossRef]

20. Lee, E.; Santana, B.V.N.; Samuels, E.; Benitez-Fuente, F.; Corsi, E.; Botella, M.A.; Perez-Sancho, J.; Vanneste, S.; Friml, J.; Macho, A.; et al. Rare earth elements induce cytoskeleton-dependent and PI4P-associated rearrangement of SYT1/SYT5 endoplasmic reticulum-plasma membrane contact site complexes in Arabidopsis. J. Exp. Bot. 2020, 71, 3986-3998. [CrossRef]

21. Ruiz-Lopez, N.; Pérez-Sancho, J.; del Valle, A.E.; Haslam, R.P.; Vanneste, S.; Catalá, R.; Perea-Resa, C.; Van Damme, D.; García-Hernández, S.; Albert, A.; et al. Synaptotagmins maintain diacylglycerol homeostasis at endoplasmic reticulum-plasma membrane contact sites during abiotic stress. Plant Cell 2021, 33, 2431-2453. [CrossRef] [PubMed]

22. Van Zelm, E.; Zhang, Y.; Testerink, C. Salt tolerance mechanisms of plants. Annu. Rev. Plant Biol. 2020, 71, 403-433. [CrossRef] [PubMed]

23. Yang, Z.; Li, J.L.; Liu, L.N.; Xie, Q.; Sui, N. Photosynthetic regulation under salt stress and salt-tolerance mechanism of sweet sorghum. Front. Plant. Sci. 2020, 10, 1722. [CrossRef]

24. Pan, T.; Liu, M.; Kreslavski, V.D.; Zharmukhamedov, S.K.; Nie, C.; Yu, M.; Kuznetsov, V.V.; Allakhverdiev, S.I.; Shabala, S Non-stomatal limitation of photosynthesis by soil salinity. Crit. Rev. Environ. Sci. Technol. 2021, 51, 791-825. [CrossRef]

25. Awlia, M.; Nigro, A.; Fajkus, J.; Schmoeckel, S.M.; Negrão, S.; Santelia, D.; Trtílek, M.; Julkowska, M.M.; Panzarová, K. Highthroughput non-destructive phenotyping of traits that contribute to salinity tolerance in Arabidopsis thaliana. Front. Plant. Sci. 2016, 7, 1414. [CrossRef] [PubMed]

26. Chaves, M.M.; Flexas, J.; Pinheiro, C. Photosynthesis under drought and salt stress: Regulation mechanisms from whole plant to cell. Ann. Bot. 2009, 103, 551-560. [CrossRef]

27. Nawaz, K.; Hussain, K.; Majeed, A.; Khan, F.; Afghan, S.; Ali, K. Fatality of salt stress to plants: Morphological, physiological and biochemical aspects. Afr. J. Biotechnol. 2010, 9, 5475-5480.

28. Ashraf, M.H.P.J.C.; Harris, P.J. Photosynthesis under stressful environments: An overview. Photosynthetica 2013, 51, 163-190. [CrossRef]

29. Deinlein, U.; Stephan, A.B.; Horie, T.; Luo, W.; Xu, G.; Schroeder, J.I. Plant salt-tolerance mechanisms. Trends. Plant Sci. 2014, 19, 371-379. [CrossRef]

30. Safdar, H.; Amin, A.; Shafiq, Y.; Ali, A.; Yasin, R.; Shoukat, A.; Hussan, M.U.; Sarwar, M.I. A review: Impact of salinity on plant growth. Nat. Sci. 2019, 17, 34-40. 
31. Arif, Y.; Singh, P.; Siddiqui, H.; Bajguz, A.; Hayat, S. Salinity induced physiological and biochemical changes in plants: An omic approach towards salt stress tolerance. Plant Physiol. Biochem. 2020, 156, 64-77. [CrossRef]

32. Lawson, T.; Vialet-Chabrand, S. Speedy stomata, photosynthesis and plant water use efficiency. New Phytol. 2019, 221, 93-98. [CrossRef] [PubMed]

33. Lawson, T.; Blatt, M.R. Stomatal size, speed, and responsiveness impact on photosynthesis and water use efficiency. Plant Physiol. 2014, 164, 1556-1570. [CrossRef] [PubMed]

34. Vialet-Chabrand, S.R.M.; Matthews, J.S.; McAusland, L.; Blatt, M.R.; Griffiths, H.; Lawson, T. Temporal dynamics of stomatal behavior: Modeling and implications for photosynthesis and water use. Plant Physiol. 2017, 174, 603-613. [CrossRef] [PubMed]

35. Ball, M.C.; Anderson, J.M. Sensitivity of photosystems II to $\mathrm{NaCl}$ in relation to salinity tolerance. Comparative studies with thylakoids of the salt tolerant mangrove, Avicennia marina, and the salt-sensitive pea, Pisum sativum. Funct. Plant. Biol. 1986, 13, 689-698. [CrossRef]

36. Takahashi, S.; Murata, N. How do environmental stresses accelerate photoinhibition? Trends Plant Sci. 2008, 13, 178-182. [CrossRef] [PubMed]

37. Pompelli, M.F.; Ferreira, P.P.B.; Chaves, A.R.M.; Figueiredo, R.C.B.Q.; Martinse, A.O.; Jarma-Orozco, A.; Bhatt, A.; Batista-Silva, W.; Endres, L.; Araújo, W.L. Physiological, metabolic, and stomatal adjustments in response to salt stress in Jatropha curcas. Plant Physiol. Biochem. 2021, 168, 116-127. [CrossRef]

38. Ouerghi, Z.; Cornic, G.; Roudani, M.; Ayadi, A.; Brulfert, J. Effect of $\mathrm{NaCl}$ on photosynthesis of two wheat species (Triticum durum and T. aestivum) differing in their sensitivity to salt stress. J. Plant Physiol. 2000, 156, 335-340. [CrossRef]

39. Steduto, P.; Albrizio, R.; Giorio, P.; Sorrentino, G. Gas-exchange response and stomatal and non-stomatal limitations to carbon assimilation of sunflower under salinity. Environ. Exp. Bot. 2000, 44, 243-255. [CrossRef]

40. Sui, N.; Yang, Z.; Liu, M.; Wang, B. Identification and transcriptomic profiling of genes involved in increasing sugar content during salt stress in sweet sorghum leaves. BMC Genom. 2015, 16, 534. [CrossRef]

41. $\mathrm{Hu}, \mathrm{T} . ; \mathrm{Yi}, \mathrm{H} . ; \mathrm{Hu}, \mathrm{L} . ; \mathrm{Fu}, \mathrm{J}$. Stomatal and metabolic limitations to photosynthesis resulting from $\mathrm{NaCl}$ stress in perennial ryegrass genotypes differing in salt tolerance. J. Am. Soc. Hortic. Sci. 2013, 138, 350-357. [CrossRef]

42. Bai, J.; Qin, Y.; Liu, J.; Wang, Y.; Sa, R.; Zhang, N.; Jia, R. Proteomic response of oat leaves to long-term salinity stress. Environ. Sci. Pollut. Res. Int. 2017, 24, 3387-3399. [CrossRef] [PubMed]

43. Najar, R.; Aydi, S.; Sassi-Aydi, S.; Zarai, A.; Abdelly, C. Effect of salt stress on photosynthesis and chlorophyll fluorescence in Medicago truncatula. Plant Biosyst.-Int. J. Deal. Asp. Plant Biol. 2019, 153, 88-97. [CrossRef]

44. Sarabi, B.; Fresneau, C.; Ghaderi, N.; Bolandnazar, S.; Streb, P.; Badeck, F.W.; Citerine, S.; Tangama, M.; David, A.; Ghashghaie, J. Stomatal and non-stomatal limitations are responsible in down-regulation of photosynthesis in melon plants grown under the saline condition: Application of carbon isotope discrimination as a reliable proxy. Plant Physiol. Biochem. 2019, 141, 1-19. [CrossRef]

45. Franzoni, G.; Cocetta, G.; Trivellini, A.; Ferrante, A. Transcriptional regulation in rocket leaves as affected by salinity. Plants 2020, 9, 20. [CrossRef]

46. Pavlovič, A.; Singerová, L.; Demko, V.; Šantrůček, J.; Hudák, J. Root nutrient uptake enhances photosynthetic assimilation in prey-deprived carnivorous pitcher plant Nepenthes talangensis. Photosynthetica 2010, 48, 227-233. [CrossRef]

47. Zörb, C.; Herbst, R.; Forreiter, C.; Schubert, S. Short-term effects of salt exposure on the maize chloroplast protein pattern. Proteomics 2009, 9, 4209-4220. [CrossRef]

48. Razavizadeh, R.; Ehsanpour, A.A.; Ahsan, N.; Komatsu, S. Proteome analysis of tobacco leaves under salt stress. Peptides 2009, 30, 1651-1659. [CrossRef]

49. Kang, G.; Li, G.; Zheng, B.; Han, Q.; Wang, C.; Zhu, Y.; Guo, T. Proteomic analysis on salicylic acid-induced salt tolerance in common wheat seedlings (Triticum aestivum L.). Biochim. Biophys. Acta 2012, 1824, 1324-1333. [CrossRef]

50. Ma, H.; Song, L.; Shu, Y.; Wang, S.; Niu, J.; Wang, Z.; Yu, T.; Gu, W.; Ma, H. Comparative proteomic analysis of seedling leaves of different salt tolerant soybean genotypes. J. Proteom. 2012, 75, 1529-1546. [CrossRef]

51. De Abreu, C.E.B.; dos Santos Araújo, G.; de Oliveira Monteiro-Moreira, A.C.; Costa, J.H.; de Brito Leite, H.; Moreno, F.B.M.B.; Prisco, J.T.; Gomes-Filho, E. Proteomic analysis of salt stress and recovery in leaves of Vigna unguiculata cultivars differing in salt tolerance. Plant Cell Rep. 2014, 33, 1289-1306. [CrossRef]

52. Wang, L.; Liu, X.; Liang, M.; Tan, F.; Liang, W.; Chen, Y.; Lin, Y.; Huang, L.; Xing, J.; Chen, W. Proteomic analysis of salt-responsive proteins in the leaves of mangrove Kandelia candel during short-term stress. PLoS ONE 2014, 9, e83141. [CrossRef] [PubMed]

53. Fatehi, F.; Hosseinzadeh, A.; Alizadeh, H.; Brimavandi, T.; Struik, P.C. The proteome response of salt-resistant and salt-sensitive barley genotypes to long-term salinity stress. Mol. Biol. Rep. 2012, 39, 6387-6397. [CrossRef]

54. Wang, J.; Meng, Y.; Li, B.; Ma, X.; Lai, Y.; Si, E.; Yang, K.E.; Xu, X.; Shang, X.; Wang, H.; et al. Physiological and proteomic analyses of salt stress response in the halophyte Halogeton glomeratus. Plant Cell Environ. 2015, 38, 655-669. [CrossRef]

55. Liu, Y.L.; Shen, Z.J.; Simon, M.; Li, H.; Ma, D.N.; Zhu, X.Y.; Zheng, H.L. Comparative proteomic analysis reveals the regulatory effects of $\mathrm{H}_{2} \mathrm{~S}$ on salt tolerance of mangrove plant Kandelia obovata. Int. J. Mol. Sci. 2020, 21, 118. [CrossRef] [PubMed]

56. Hui-Hui, Z.; Guang-Liang, S.; Jie-Yu, S.; Xin, L.; Ma-Bo, L.; Liang, M.; Nan, X.; Guang-Yu, S. Photochemistry and proteomics of mulberry (Morus alba L.) seedlings under $\mathrm{NaCl}$ and $\mathrm{NaHCO}_{3}$ stress. Ecotoxicol. Environ. Saf. 2019, 184, 109624. [CrossRef] [PubMed] 
57. Xu, J.; Lan, H.; Fang, H.; Huang, X.; Zhang, H.; Huang, J. Quantitative proteomic analysis of the rice (Oryza sativa L.) salt response. PLOS ONE 2015, 10, e0120978. [CrossRef]

58. Pang, Q.; Chen, S.; Dai, S.; Chen, Y.; Wang, Y.; Yan, X. Comparative proteomics of salt tolerance in Arabidopsis thaliana and Thellungiella halophila. J. Proteome Res. 2010, 9, 2584-2599. [CrossRef]

59. Maslova, T.G.; Markovskaya, E.F.; Slemnev, N.N. Functions of Carotenoids in Leaves of Higher Plants. Biol. Bull. Rev. 2021, 11, 476-487. [CrossRef]

60. Agati, G.; Brunetti, C.; Fini, A.; Gori, A.; Guidi, L.; Landi, M.; Sebastiani, F.; Tattini, M. Are flavonoids effective antioxidants in plants? Twenty years of our investigation. Antioxidants 2020, 9, 1098. [CrossRef] [PubMed]

61. Geissler, N.; Hussin, S.; Koyro, H.W. Interactive effects of $\mathrm{NaCl}$ salinity and elevated atmospheric $\mathrm{CO}_{2}$ concentration on growth, photosynthesis, water relations and chemical composition of the potential cash crop halophyte Aster tripolium L. Environ. Exp. Bot. 2009, 65, 220-231. [CrossRef]

62. Lutts, S.; Kinet, J.M.; Bouharmont, J. NaCl-induced senescence in leaves of rice (Oryza sativa L.) cultivars differing in salinity resistance. Ann. Bot. 1996, 78, 389-398. [CrossRef]

63. Pinheiro, H.A.; Silva, J.V.; Endres, L.; Ferreira, V.M.; de Albuquerque Câmara, C.; Cabral, F.F.; dos Santos Filho, B.G. Leaf gas exchange, chloroplastic pigments and dry matter accumulation in castor bean (Ricinus communis L.) seedlings subjected to salt stress conditions. Ind. Crops Prod. 2008, 27, 385-392. [CrossRef]

64. Li, G.; Wan, S.; Zhou, J.; Yang, Z.; Qin, P. Leaf chlorophyll fluorescence, hyperspectral reflectance, pigments content, malondialdehyde and proline accumulation responses of castor bean (Ricinus communis L.) seedlings to salt stress levels. Ind. Crops Prod. 2010, 31, 13-19. [CrossRef]

65. Yang, J.Y.; Zheng, W.; Tian, Y.; Wu, Y.; Zhou, D.W. Effects of various mixed salt-alkaline stresses on growth, photosynthesis, and photosynthetic pigment concentrations of Medicago ruthenica seedlings. Photosynthetica 2011, 49, 275-284. [CrossRef]

66. Gadallah, M.A.A. Effects of proline and glycinebetaine on Vicia faba responses to salt stress. Biol. Plant 1999, $42,249-257$. [CrossRef]

67. Gautam, S.; Singh, P.K. Salicylic acid-induced salinity tolerance in corn grown under NaCl stress. Acta Physiol. Plant 2009, 31, 1185-1190. [CrossRef]

68. Karnik, R.; Waghmare, S.; Zhang, B.; Larson, E.; Lefoulon, C.; Gonzalez, W.; Blatt, M.R. Commandeering channel voltage sensors for secretion, cell turgor, and volume control. Trends Plant Sci. 2017, 22, 81-95. [CrossRef] [PubMed]

69. Südhof, T.C. Neurotransmitter release: The last millisecond in the life of a synaptic vesicle. Neuron 2013, 80, 675-690. [CrossRef]

70. Jezek, M.; Blatt, M.R. The membrane transport system of the guard cell and its integration for stomatal dynamics. Plant Physiol. 2017, 174, 487-519. [CrossRef] [PubMed]

71. Eisenach, C.; Chen, Z.H.; Grefen, C.; Blatt, M.R. The trafficking protein SYP121 of Arabidopsis connects programmed stomatal closure and $\mathrm{K}^{+}$channel activity with vegetative growth. Plant J. 2012, 69, 241-251. [CrossRef]

72. Boyes, D.C.; Zayed, A.M.; Ascenzi, R.; McCaskill, A.J.; Hoffman, N.E.; Davis, K.R.; Görlach, J. Growth stage-based phenotypic analysis of Arabidopsis: A model for high throughput functional genomics in plants. Plant Cell 2001, 13, 1499-1510. [CrossRef]

73. Lešková, A.; Kusá, Z.; Labajová, M.; Krausko, M.; Jásik, J. The Photoconvertible Fluorescent Protein Dendra2 Tag as a Tool to Investigate Intracellular Protein Dynamics. Methods Mol. Biol. 2019, 2019, 201-2014.

74. Lešková, A.; Labajová, M.; Krausko, M.; Zahradníková, A.; Baluška, F.; Mičieta, K.; Turňa, J.; Jásik, J. Endosidin 2 accelerates PIN2 endocytosis and disturbs intracellular trafficking of PIN2, PIN3, and PIN4 but not of SYT1. PLoS ONE 2020, 15, e0237448. [CrossRef]

75. Maxwell, K.; Johnson, G.N. Chlorophyll fluorescence-A practical guide. J. Exp. Bot. 2000, 51, 659-668. [CrossRef] [PubMed]

76. Martínez-García, J.F.; Monte, E.; Quail, P.H. A simple, rapid and quantitative method for preparing Arabidopsis protein extracts for immunoblot analysis. Plant. J. 1999, 20, 251-257. [CrossRef]

77. Lichtenthaler, H.K. Chlorophylls and carotenoids:Pigments of photosynthetic biomembranes. Meth. Enzymol. 1987, 148, 350-382.

78. Pękal, A.; Pyrzynska, K. Evaluation of aluminium complexation reaction for flavonoid content assay. Food Anal. Meth. 2014, 7, 1776-1782. [CrossRef] 